\title{
The expression of the IGF family and GH receptor in the bovine mammary gland
}

\author{
A Plath-Gabler, C Gabler ${ }^{1}$, F Sinowatz ${ }^{2}$, B Berisha and D Schams \\ Institute of Physiology, Technical University of Munich, Weihenstephaner Berg 3, D-85350 Freising-Weihenstephan, Germany \\ ${ }^{1}$ The John O Almquist Research Centre, Department of Dairy and Animal Science, The Pennsylvania State University, University Park, Pennsylvania 16802, \\ USA \\ ${ }^{2}$ Institute of Animal Anatomy II, Ludwig-Maximilians-University Munich, Veterinärstrasse 13, D-80539 Munich, Germany \\ (Requests for offprints should be addressed to D Schams; Email: physio@weihenstephan.de)
}

\begin{abstract}
To study the involvement of the IGFs in mammary development and lactation of the cow, the temporal expressions of IGF-I and -II, its receptor type 1 (IGFR-1), IGF-binding proteins (IGFBPs) -1 to -6 and GH receptor (GHR) mRNA were examined. This was carried out for different stages of mammogenesis, lactogenesis, galactopoiesis and involution in the bovine mammary gland of 26 animals. Furthermore, IGF-I was localised by immunohistochemistry. The highest mRNA concentrations for IGF-I were detected in the mammary tissue of late pregnant heifers (days 255-272) and significantly lower expression was detected during lactogenesis and galactopoiesis. Immunohistochemistry of IGF-I revealed only a weak staining in the epithelium of the ducts during mammogenesis. The epithelium of the alveoli were negative during mammogenesis, lactogenesis and galactopoiesis but displayed distinct IGF-I activity during involution. In the stroma a distinct staining of the cytoplasm of adipocytes and of vascular smooth muscle cells was observed. A certain percentage of fibroblasts (usually 20-30\%) were also immunopositive. In contrast, highest expression for IGFR-1 was detected during galactopoiesis and involution. The lowest mRNA concentration for IGFR-1 was
\end{abstract}

found during pregnancy (days 194-213). In general, the expression of IGF-II was not regulated during mammogenesis and lactation, but decreased during involution. The mRNA for the six binding proteins was detected in the bovine mammary gland. The dominant binding proteins were IGFBP-3 and -5 . The highest expression of IGFBP-3 was observed during mid-pregnancy and the lowest during late lactation, involution and in nonpregnant heifers. The mRNA for IGFBP-5 increased during late mammogenesis and lactogenesis followed by a decrease thereafter. In general, the mRNA concentrations for IGFBP-2 , -4 and -6 were barely detectable during all stages. In contrast, the expression for IGFBP-1 was upregulated in the mammary gland of virgin heifers and increased around the onset of lactation. mRNA for GHR was found during all stages examined without outstanding fluctuations.

In conclusion, locally produced IGF-I and -II may mediate mammogenesis. The high mammary IGFR-1 mRNA during lactation suggests a role for peripheral IGF-I in maintenance of lactation. The role of IGFBPs in the mammary gland needs further evaluation.

Journal of Endocrinology (2001) 168, 39-48

\section{Introduction}

The insulin-like growth factor (IGF) and growth hormone $(\mathrm{GH})$ system is important for the regulation of mammalian epithelial cell proliferation and differentiation. IGF may act as mediator of GH during mammary development and differentiation in ruminants (Gluckmann \& Breier 1987, Breier \& Sauerwein 1995). No GH binding to ruminant mammary tissue in vitro has been detected (Hauser et al. 1990); however, GH mRNA is expressed in epithelial cells (Glimm et al. 1990). IGF-I is believed to mediate galactopoietic effects from exogenous bovine GH in the cow (Karg et al. 1988, Sharma et al. 1994). IGF-I can act in a paracrine or endocrine manner (Holly \& Wass 1989). IGF-I mRNA was detected in the bovine mammary gland (Glimm et al. 1992), although not in the epithelial cells. The liver is supposed to be the primary source of circulating IGF-I, which may affect target tissues such as the mammary gland. IGFs are potent mitogens involved in the regulation of cell proliferation and apoptosis. The action of IGFs seems to be mediated mainly through a specific cell membrane receptor called IGF receptor type 1 (IGFR-1) (Jones \& Clemmons 1995). It binds IGF-I with a higher affinity than IGF-II or insulin. The IGFR-2 is more specific for IGF-II than for IGF-I and does not bind insulin (Massague \& Czech 1982, Rechler \& Nissley 
1985). Different IGFR-1 mRNA transcripts have been detected in the bovine mammary gland (Glimm et al. 1992).

IGF-binding proteins (IGFBPs) regulate the interaction between IGFs and their receptors. At least six IGFBPs have been described (Ballard et al. 1989) and several (IGFBP-2 to -5) have been detected also in cows' milk (Campbell et al. 1991, reviewed in Baumrucker et al. 1993). Bovine mammary cells in culture produce and secrete at least four species of binding proteins (McGrath et al. 1991).

Published data point towards a role of the IGF system during developmental or apoptotic processes in the mammary gland. However, very little is known about the different stages of these processes in ruminants. The aim of this descriptive study was to examine the expression pattern of IGF-I and -II and IGFR-1 and GH receptor (GHR) during defined stages of mammary growth and lactation in the cow. Furthermore, the expression of the six binding proteins was studied to gain insight into their possible functions in the bovine mammary gland. Finally, the localisation of IGF-I was evaluated by immunohistochemistry. All together the data should help in more experimentally oriented future studies to discover the possible role of the IGF system in the mammary gland.

\section{Materials and Methods}

Animals, tissue sampling and preparation

The mammary gland from German Brown Swiss cows $(n=26)$ was removed within $20 \mathrm{~min}$ after slaughter during defined stages. Small pieces (1-2 g) of mammary tissue and liver were frozen in liquid nitrogen and stored at $-80{ }^{\circ} \mathrm{C}$. Slices of the mammary tissue for immunohistochemistry were prepared as described later on. The classification of the animals was established as follows. (i) Ductal growth (18-month-old virgin heifers, $n=4)$; lobuloalveolar development during first pregnancy. (ii) Days 194-213 of pregnancy $(n=4)$ or (iii) days 255-272 of pregnancy $(n=4)$. (iv) Lactogenesis (onset of secretion during days 5-11 post-partum, $n=4$ ); galactopoiesis. (v) Peak lactation $(n=4)$. (vi) Late lactation $(n=3)$. (vii) involution $(n=3)$; 3-4 weeks after dry-off and non-pregnant.

\section{RNA extraction}

Total RNA was isolated from bovine tissues using an adapted guanidinium thiocyanate-phenol method as described (Plath et al. 1997). The RNA was dissolved in diethylpyrocarbonate-treated water and quantified by absorbance at $260 \mathrm{~nm}$. Agarose gel electrophoresis and ethidium bromide staining verified quantity and quality.

\section{RT-PCR}

Four micrograms of RNA were used for the cDNA synthesis as described previously (Plath et al. 1997).
Conditions for the enzymatic amplification were optimised for all the factors studied. For every PCR amplification the linear range was verified by introducing increasing cDNA amounts as well as cycle numbers. Each PCR contained $8 \mathrm{mM}$ Tris- $\mathrm{HCl}, 4 \mathrm{mM} \mathrm{KCl}, 1.5 \mathrm{mM}$ $\mathrm{MgCl}_{2}, 0.08 \%$ Triton $\mathrm{X}-100,0.6 \mu \mathrm{M}$ of each primer (except for ubiquitin: $1 \cdot 3 \mu \mathrm{M}$ ), 0.5 units Taq Polymerase PrimeZyme (Biometra, Goettingen, Germany) and cDNA derived by reverse transcription of $0.33 \mu \mathrm{g}$ RNA in a final volume of $25 \mu \mathrm{l}$. Amplification conditions included 30 (IGF-I and -II, GHR), 35 (IGFR-1, IGFBP-3), 37 (IGFBP-1, -4 and -5 ) and 40 cycles (IGFBP-2 and -6) of denaturation at $94{ }^{\circ} \mathrm{C}$ for $1 \mathrm{~min}$, annealing at $60{ }^{\circ} \mathrm{C}\left(55^{\circ} \mathrm{C}\right.$ IGFR-1, $63^{\circ} \mathrm{C}$ IGF-I, IGFBP-5 and GHR) for $1 \mathrm{~min}$. A single denaturation step at $94^{\circ} \mathrm{C}$ for $2 \mathrm{~min}$ and a final extension step at $72^{\circ} \mathrm{C}$ for 2 min were performed, except for ubiquitin: 19 cycles of denaturation at $94^{\circ} \mathrm{C}$ for $45 \mathrm{~s}$, annealing at $55^{\circ} \mathrm{C}$ for $45 \mathrm{~s}$ and extension at $72{ }^{\circ} \mathrm{C} 45 \mathrm{~s}$. The primers encoding the bovine sequences were as followed: for IGF-I 5'-GGG CTG AGT TGG TGG ATG-3', rev 5'-CTC CAG CCT CCT CAG ATC AC-3'; for IGF-II 5'-TAT GCT GCT TAC CGC CCC AG-3', rev 5'-ACA TCC CTC TCG GAC TTG GC-3'; for IGFR-1 5'-TTA AAA TGG CCA GAA CCT GAG$3^{\prime}$, rev $5^{\prime}$-ATT ATA ACC AAG CCT CCC AC-3'; for IGFBP-1 5'-AGC CCA GAG AAT GTG TCC C-3', rev 3'-TTC TTG TTG CAG TTT GGC AG-3'; for IGFBP-2 5'-ACT GTC ACA AGC ATG GCC TG-3' (Winger et al. 1997), rev 5'-CCT CCT GCT GCT CAT TGT AGA-3'; for IGFBP-3 5'-TGC GCC CTT ACC TGC TAC-3', rev 5'-CAG TTG GGA ATG TGG ATG C-3'; for IGFBP-4 5'-GCC CTG TGG GGT GTA CAC-3', rev 5'-TGC AGC TCA CTC TGG CAG-3'; for IGFBP-5 5'-TGC GAG CTG GTC AAG GAG -3', rev 5'-TCC TCT GCC ATC TCG GAG -3'; for IGFBP-6 5'-AGA AAG AGG ATT TGC CTT TGC-3', rev 5'-TCC GGT AGA AGC CCC TAT G-3'; for GHR 5'-AGA TGG GAT GGA TAA TCC TGG-3', rev 5'-TCT TTG GAA CTG GAA CTG GG-3'; for ubiquitin 5'-ATG CAG ATC TTT GTG AAG AC-3' (Gabler et al. 1997), rev 5' -CTT CTG GAT GTT GTA GTC- 3'.

PCR products were analysed by agarose gel electrophoresis, and double-strand sequencing (Sequiserve, Vaterstetten, Germany) was done to verify the obtained amplification products. However, RT-PCR and the evaluation technique used is relative and not a strictly quantitative method. The cDNA levels of the housekeeping gene ubiquitin were almost equal throughout the different stages with a tendency to decrease during lactation and involution (data not shown).

\section{RNase protection assay (RPA)}

The RPA was performed and validated as described (Plath et al. 1996). Briefly, for IGF-I, pooled total mammary 
RNA $(20 \mu \mathrm{g})$ was introduced into a commercial RPA (Ambion, Austin, TX, USA); the RNase dilution employed was 1:100 and hybridisation was carried out overnight $(16 \mathrm{~h})$ at $45{ }^{\circ} \mathrm{C}$. Precast $10 \%$ polyacrylamide gels were supplied with $7 \mathrm{M}$ urea (Cleangels; Pharmacia, Freiburg, Germany). Sense and radiolabelled antisense riboprobes were generated by subcloning of the desired homologous gene products (PCR cloning and RNAtranscription kit; Stratagene, La Jolla, CA, USA). Increasing amounts of in vitro-synthesised sense RNA for IGF-I were hybridised with the respective labelled riboprobe and compared with a standard mammary RNA sample to allow a quantification of the mRNA.

\section{Immunohistochemistry}

For histology and immunohistochemistry, tissue samples (approximately $15 \mathrm{~mm}$ long and $5 \mathrm{~mm}$ thick) were fixed in Bouin's solution or in methanol/glacial acid (ratio 1:1, $\mathrm{w} / \mathrm{v}$ ) for $24 \mathrm{~h}$, dehydrated in graded series of ethanol, cleared in xylene and embedded in paraffin. Serial sections $(5 \mu \mathrm{m})$ were cut on a microtome and mounted on glass slides.

Following deparaffinisation, the presence of IGF-I was demonstrated immunohistochemically by the streptavidinbiotin horseradish peroxidase complex technique (Hsu et al. 1981). Endogenous peroxidase activity was eliminated by incubation with $0.5 \%(\mathrm{v} / \mathrm{v})$ hydrogen peroxide solution in absolute methanol for $15 \mathrm{~min}$ at $20^{\circ} \mathrm{C}$. Non-specific protein binding was eliminated by incubation with $20 \%$ normal goat serum in PBS for $1 \mathrm{~h}$ at $20^{\circ} \mathrm{C}$. Sections were then incubated (i) for $18 \mathrm{~h}$ at $4{ }^{\circ} \mathrm{C}$ with a rabbit polyclonal antibody to IGF-I (KI801, dilution 1:1600; A. Skottner Kabi Pharmacia, Stockholm, Sweden), (ii) for $1 \mathrm{~h}$ with biotinylated goat anti-rabbit IgG (Amersham-Pharmacia, Freiburg, Germany, diluted 1:200 in PBS-1\% BSA) and (iii) for $1 \mathrm{~h}$ at $20^{\circ} \mathrm{C}$ with streptavidin horseradish peroxidase complex, diluted 1:250 in PBS-1\% BSA.

Visualisation was achieved by incubation for $5 \mathrm{~min}$ in $0.5 \mathrm{mg} / \mathrm{ml}$ diaminobenzidine in PBS containing 1\% hydrogen peroxide. Between each step sections were washed three times in PBS and once in PBS-1\% BSA. All incubations were carried out in humidified chambers to prevent evaporation. Sections were left un-counterstained or nuclei were lightly counterstained in Mayer's haematoxylin, and were dehydrated, cleared and mounted.

Controls were performed by (i) replacing the IGF-I antibody with unrelated primary antibodies (Brucella abortus Mab, Mab 50.8; Agen, Brisbane, Austria) at the same or greater concentration, (ii) substituting the anti-IGF-I antibody with normal rabbit serum at different concentrations and (iii) omission of the primary antibody.

\section{Statistical analysis}

When the data subjected to one-way ANOVA showed significant differences, a Bonferroni test was performed.

\section{Results}

Expression of IGF family members during different developmental and functional stages

The obtained partial PCR sequences for IGF-I (155 bp), IGF-II (215 bp), IGFBP-1 (275 bp), IGFBP-2 (168 bp), IGFBP-3 (346 bp), IGFBP-4 (342 bp), IGFBP-5 (257 bp), IGFBP-6 (324 bp), IGFR-1 (314 bp) and GHR (366 bp) were 100\% homologous to the known bovine sequences (see Fig. 1 for the different PCR products and the corresponding sizes).

IGF-I mRNA expression was analysed by RT-PCR and RPA. The highest IGF-I mRNA concentration was found in the mammary tissue of the virgin and pregnant heifers when compared with the even higher concentration in the liver. The expression decreased significantly $(P<0 \cdot 05)$ during lactogenesis and galactopoiesis followed by an increase during involution (Figs 2 and 3). Furthermore, comparison between increasing amounts of in vitrosynthesised sense RNA and mammary RNA during RPA analysis showed that approximately $0.5 \mathrm{pg}$ IGF-I $\mathrm{mRNA} / \mu \mathrm{g}$ RNA was contained in non-lactating mammary tissue (data not shown).

The densitometric analysis of the RT-PCR of IGF-I and $-\mathrm{II}$, IGFR-1 and IGFBP-1, -3 and -5 during the different stages examined are shown with the most representative bands in Fig. 2. The expression pattern presented for IGF-I was confirmed by RPA (Fig. 3). Due to the higher sensitivity of the PCR, the lower mRNA expression throughout lactation was detectable. The relative IGF-I mRNA concentration of the virgin heifers was slightly lower when compared with the RPA analysis.

Relative expression of IGF-II mRNA (Fig. 3) showed no significant differences during mammogenesis, lactogenesis and lactation and decreased significantly during involution $(P<0 \cdot 05)$.

The highest IGFR-1 mRNA concentration was detected during late lactation and involution and the lowest during mammogenesis (days 194-213 of pregnancy). In the liver sample no IGFR-1 expression was detected. The IGFBP-3 mRNA concentrations were statistically different only during early mammogenesis and decreased thereafter to significantly lower levels during late lactation and involution. The IGFBP-5 mRNA concentration showed a clear upregulation during late mammogenesis and lactogenesis $(P<0 \cdot 05)$, followed by a decrease thereafter.

IGFBP-1 showed an upregulation in virgin heifers $(P<0 \cdot 05$, when compared with all the other stages) and during early lactation. IGFBP-4 mRNA (data not shown) was increased only weakly during late mammogenesis and lactogenesis.

For IGFBP-2 and -6 only very weak non-regulated signals were detected. A signal of GHR mRNA was found without any significant change throughout all stages of the mammary gland examined (data not shown). 


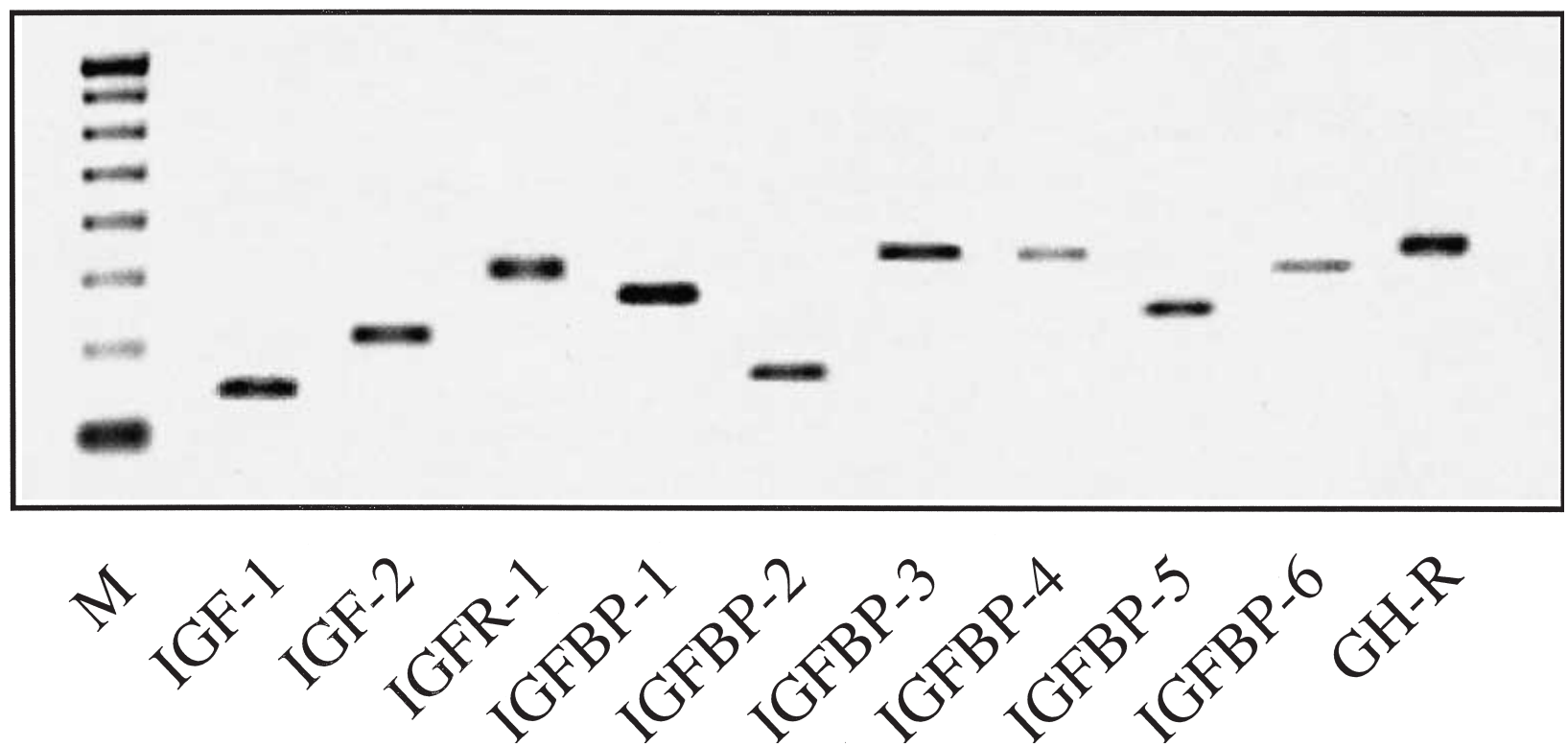

Figure 1 Specific RT-PCR products for IGF-I and -II, IGFR-1, IGFBP-1, -2, -3, -4, -5 and -6 and GHR separated by agarose gel electrophoresis in the bovine mammary gland of virgin heifers as an example for the expression of these factors. $M=100$ bp marker.

\section{Immunohistochemistry}

Mammogenesis Mammogenesis in non-pregnant heifers. Mammogenesis in non-pregnant heifers was mainly characterised by ductal growth. The mammary gland was characterised by a well-developed adipose tissue in which small groups of ducts were seen. The comparatively wide lumina of the ducts were lined by a two-layered epithelium with cuboidal luminal secretory cells and a basal layer of myoepithelial cells. Three or four layers of condensed connective tissue surrounded the ductular epithelium. Between the ducts, areas of loose connective tissue were seen, which contained comparatively few cells. As shown in Fig. $4 a$ and $b$ the luminal layer of the ductular epithelium was negative or displayed only weak immunostaining for IGF-I. The basal layer comprising the myoepithelial cells was negative. Ten per cent of the fibroblasts in the interlobular stroma appeared positive for immunoreactive IGF-I. The endothelium of blood and lymph vessels was always negative, whereas smooth muscle cells of blood and lymph vessels were distinctly immunopositive. Many of the adipocytes (about $80 \%$ ) showed a distinct perinuclear IGF staining in their cytoplasm.

Days 194-213 of pregnancy of primigravid heifers. At the beginning of this period (day 194) the alveoli were well developed to lobuli. The alveoli were small, roundish and lined by a cuboidal epithelium which appeared negative for immunoreactive IGF-I. The flat myoepithelial cells under the secretory epithelial cells were difficult to see and were usually negative for imunoreactive IGF-I. The adipose tissue was well developed at the beginning and displayed a distinct IGF-I staining. Later in this period the fat cells were reduced. At day 204 about 60-70 alveoli per section were seen to be surrounded by one or two layers of fat cells followed by connective tissue. The glandular epithelium was always negative. In several alveolar epithelial cells small lipid droplets occurred. In the stroma no significant changes were seen. About $20-30 \%$ of the fibroblasts were IGF-I positive. The vascular endothelium was not immunostained, but the smooth muscle cells were generally distinctly IGF-I positive. Adipocytes were generally IGF-I positive in their perinuclear cytoplasm.

Days 255-272 of pregnancy of primigravid heifers. During late pregnancy the amount of adipose tissue around the lobuli was further reduced, but the remaining fat cells appeared still immunoreactive for IGF-I in the cytoplasmic area around their nuclei. The height of the alveolar epithelium increased and varied between cuboidal and columnar. Many lipid droplets were seen in the alveolar cytoplasm. No immunostaining for IGF-I was seen in the secretory epithelial and myoepithelial cells. The epithelium of the ducts was always IGF-I negative. No significant changes were seen in the stroma. Some moderately immunostained fibroblasts occurred in the interlobular stroma. Endothelium of blood and lymph vessels was negative whereas smooth muscle cells of the vessels were moderately to distinctly stained.

Lactogenesis (days 5-11 post-partum) The lobuli of the mammary gland consisted of numerous alveoli with wide lumina separated by small amounts of connective tissue (Fig. 4c). Within the alveoli a large amount of secretion occurred. Within the glandular epithelial cells of 
IGF-1

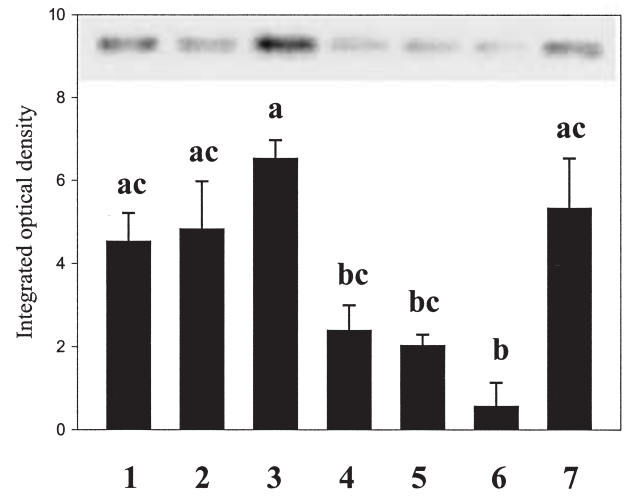

IGFBP-3

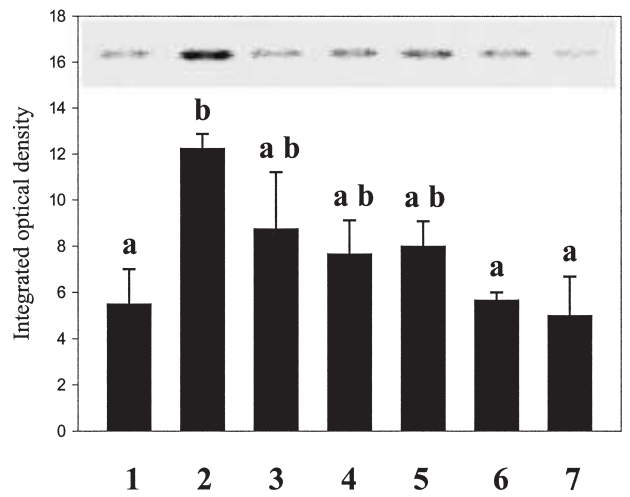

\section{IGFR-1}

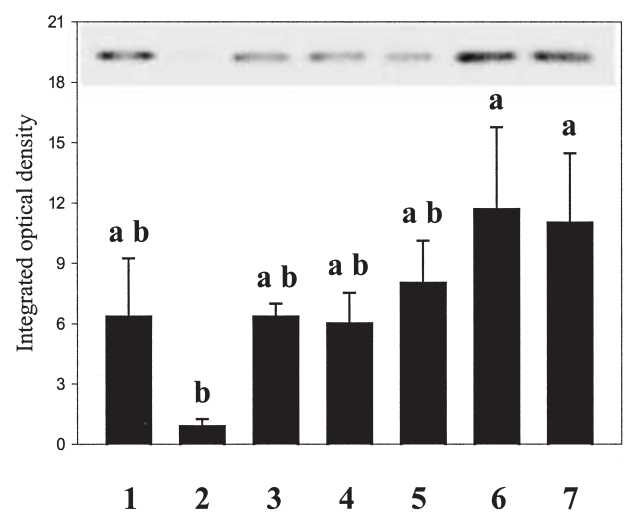

IGF-2

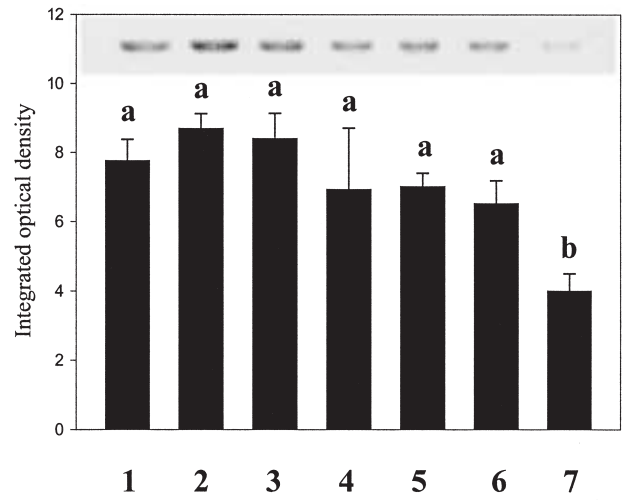

IGFBP-1

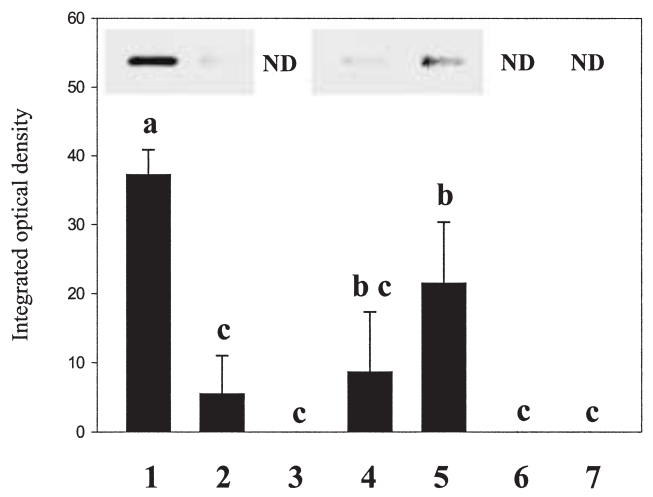

IGFBP-5

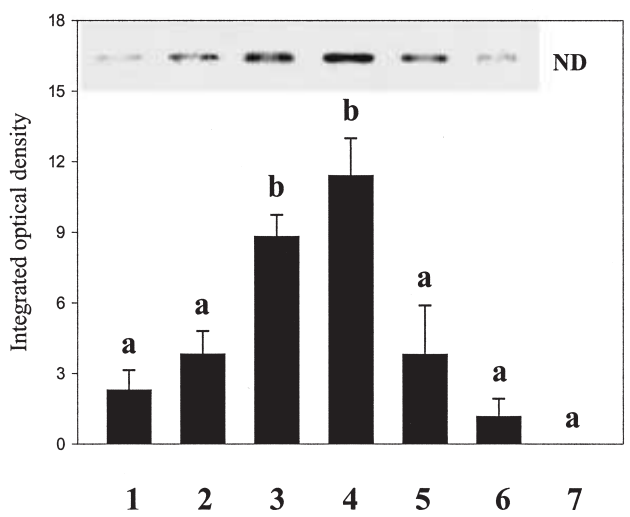

Figure 2 Densitometrically analysed RT-PCR of IGF-I and -II, IGFBP-1, -3 and -5 and IGFR-1 from virgin heifers (column 1), primigravid heifers between days 194 and 213 of pregnancy (column 2), primigravid heifers between days 255 and 272 of pregnancy (column 3), during lactogenesis (column 4), during peak lactation (column 5), during late lactation (column 6) and during involution (column 7). Data from densitometric analysis are shown as means \pm S.E.M.; for IGF-I $n=3,3,3,3,3$, 3, 3; for IGF-II $n=4$, 4, 4, 3, 4, 3, 4; for IGFBP-3 $n=4$, 4, 4, 3, 4, 3, 4; for IGFBP-1 $n=4$, 4, 4, 3, 4, 3, 4; for IGFR-1 $n=4,4,3,3,4$, 3, 3; for IGFBP-5 n=4, 4, 4, 3, 4, 3, 4 . Significant differences $(P<0 \cdot 05)$ are indicated for IGF-I and -II, IGFR-1 and IGFBP-1, -3 and -5 . ND=not detected. The upper panel depicts the most representative bands during each stage. 


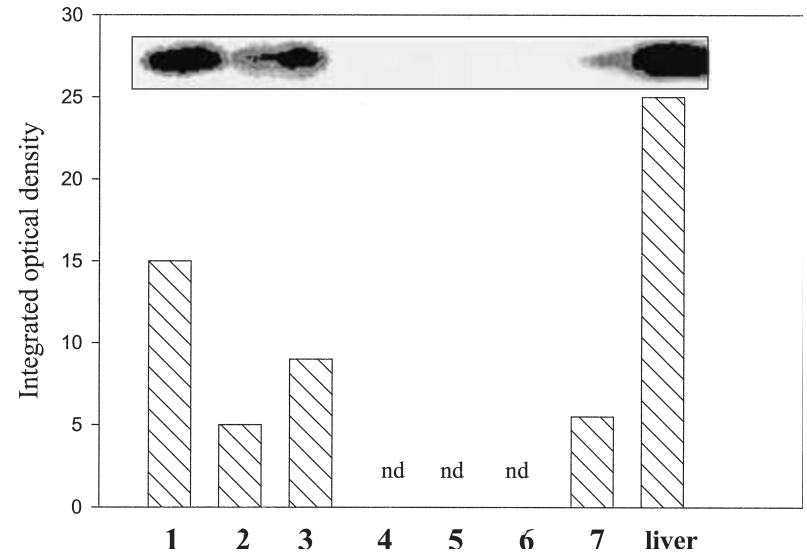

Figure 3 Densitometrically analysed RPA of IGF-I. Columns represent pooled mammary RNA $(20 \mu \mathrm{g}, n=4)$ from virgin heifers (column 1), from primigravid heifers between days 194 and 213 of pregnancy (column 2), from primigravid heifers between days 255 and 272 of pregnancy (column 3), during lactogenesis (column 4), during peak lactation (column 5), during late lactation (column 6), during involution (column 7) and in the liver. nd=not detected. The upper panel depicts original results of the RPA.

the distended alveoli numerous lipid droplets of varying size were seen. The secretory epithelial cells showed a weak staining for immunoreactive IGF-I. The myoepithelial cells were always negative. A few fat cells, which showed distinct IGF-I immunoreactivity, were seen in the periphery of the lobuli. In the interlobular stroma most of the fibroblast were immunonegative. Endothelium of blood and lymph vessels was negative and smooth muscle cells of the blood and large lymph vessels stained weakly for IGF-I.

Galactopoiesis Peak lactation. In the 10th week of lactation the secretory cells and myoepithelial cells of the alveoli were negative for immunoreactive IGF-I (Fig. 4d). Some of the fibroblasts in the interlobular stroma were weakly positive but a fair number of distinctly IGF-Ipositive macrophages appeared, which were also seen in the intralobular connective tissue. No significant changes were seen in the blood vessels. Their endothelium was negative and their smooth muscle layer appeared weakly to distinctly IGF-I immunopositive.

Late lactation. In cows lactating for 13 months the appearance of the mammary parenchyma changed significantly. The alveoli were irregular in their outline and were lined by a secretory epithelium, which varied between flat and columnar in its height. Many lumina containing a high amount of secretory material corpora amylacea were seen. At the periphery of the lobuli small alveoli with a columnar epithelium and a small lumen occurred. No IGF-I immunoreactivity was seen in either the secretory or myoepithelial cells of any of the acini or ducts. The number of weakly IGF-I-positive fat cells in the stroma was low. A few fibroblasts of the interalveolar stroma were weakly IGF-I immunoreactive. A significant number of macrophages were seen in the intralobular stroma and contained a high amount of immunoreactive IGF-I. As in the previous stages, endothelium of blood and lymph vessels did not show any immunostaining for IGF-I.

\section{Involution of the mammary gland}

In non-pregnant cows which were dry for 3 or 4 weeks the size and outline of the acini showed a wide variation. Lobuli with small and roundish acini were distributed between areas with large acini with an irregular outline and a folded epithelium. The cubic epithelium of the small acini as well as that of the large ones displayed a distinct immunoreactivity for IGF-I (Fig. 4e). In the lumina of the acini neutrophilic granulocytes frequently occurred with a varying IGF staining (weak to distinct) in their cytoplasm. The epithelium of the ducts was also distinctly stained. The density of the intralobular stroma had increased considerably and it stained weakly for IGF-I. Many macrophages were easily discerned by their pronounced staining for IGF-I, whereas groups of lymphocytes were consistently seen in the stroma, and were always negative. A weak to distinct IGF-I immunoreactivity occurred in the adipose tissue and the vascular smooth muscle cells.

Figure 4 (Opposite) Immunohistochemistry of IGF-I. (a) Bovine mammary gland, non-pregnant heifer. No immunoreactive IGF-I is seen in the ductular epithelium. (b) Bovine mammary gland, non-pregnant heifer. The endothelium of blood and lymph vessels appears always negative whereas smooth muscle cells of blood and lymph vessels are distinctly immunopositive for IGF-I. Many of the adipocytes (about 80\%) show a distinct perinuclear IGF staining in their cytoplasm. (c) Bovine mammary gland, day 6 post-partum. The alveolar epithelium displays a weak reaction for immunoreactive IGF-I. (d) Bovine mammary gland, galactopoiesis, 4th week of lactation. The secretory cells and myoepithelial cells of the alveoli are negative for immunoreactive IGF-I. Some of the fibroblasts in the interlobular stroma are weakly positive but a fair number of distinctly IGF-I-positive macrophages appear. (e) Bovine mammary gland, 4th week of dry period. The cubic epithelium of the small acini, which contains large lipid droplets, as well as that of the large ones displays a distinct immunoreactivity for IGF-I. In the lumina of the acini frequently neutrophilic granulocytes occur with a varying IGF staining (weak to distinct) in their cytoplasm. (f) Bovine mammary gland, 8th week of dry period. The epithelium of the ducts and some remaining small alveoli is distinctly IGF-I immunopositive. The density of the intralobular stroma has considerably increased and it stains weakly for IGF-I. Many macrophages can be easily discerned by their pronounced staining for IGF-I, whereas groups of lymphocytes also regularly seen in the stroma are always negative. A weak to distinct IGF-I immunoreactivity occurs in the adipose tissue and the vascular smooth muscle cells. Bars are $100 \mu \mathrm{m}$ throughout. 

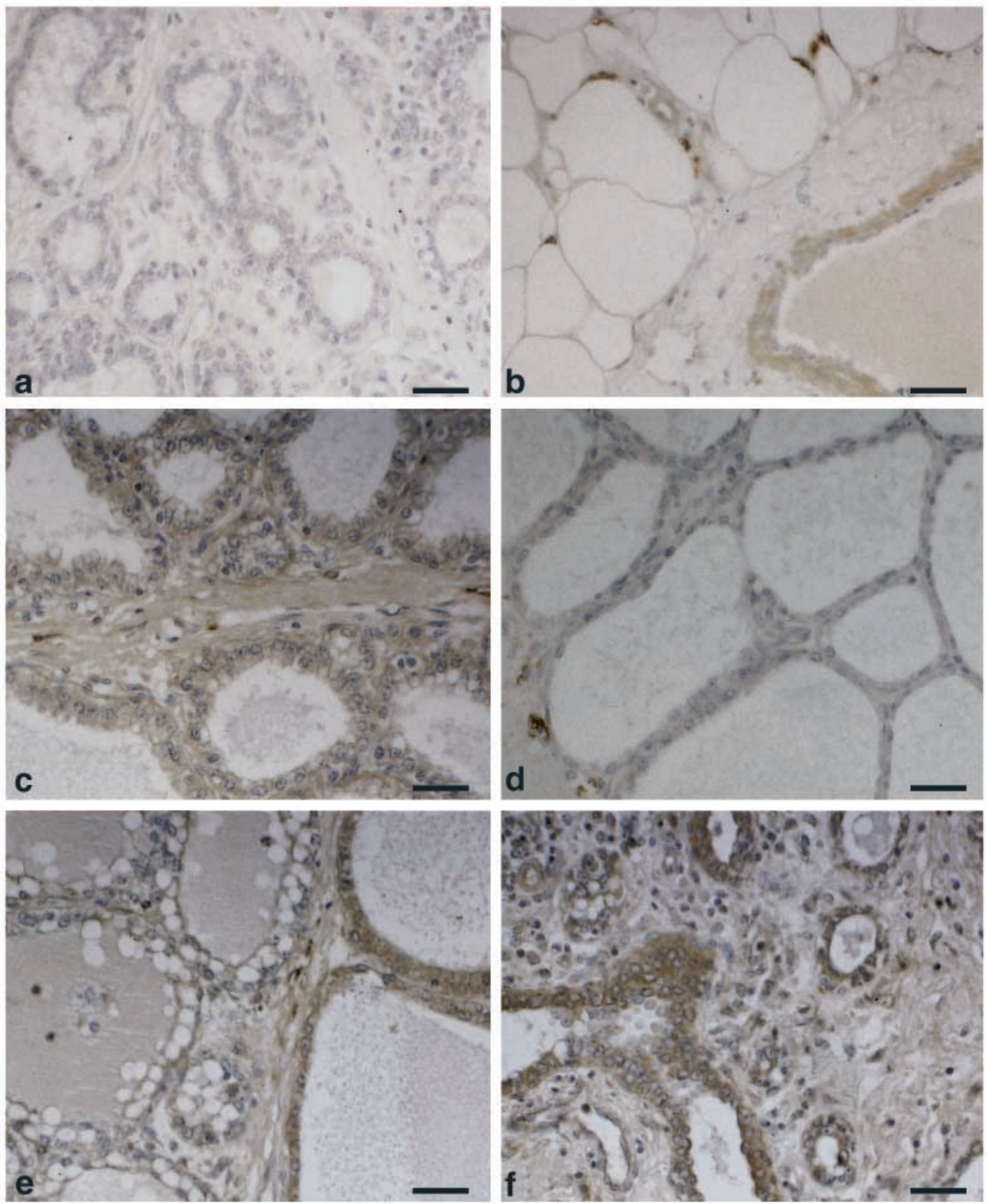


\section{Discussion}

The mRNA of the investigated factors was detected in the bovine mammary gland, suggesting paracrine and endocrine functions.

In general, the higher mRNA expression of IGF-I during mammogenesis when compared with lactation indicates a potential proliferative role throughout development. Nevertheless, the possibility of a dilution effect due to increased milk protein mRNA expression during lactation must be considered. The changes in ubiquitin mRNA concentrations were considerably smaller than those observed for IGF mRNA. This fact, and different expression patterns observed for the different factors, corroborate the notion of a specific control of the expression in the bovine mammary gland. Neither the GHR nor the IGFR-1 mRNA concentration decreased with the onset of lactation. This decrease of the IGF-I mRNA concentration in the bovine mammary tissue may be species specific, since it was not observed in the sow (Lee et al. 1993). As expected, the mammary IGF-I mRNA expression was lower as in the liver, although the mammary IGF-I mRNA concentration of the virgin heifers was relatively high. Histologically the mammary gland was characterised by a well-developed adipose tissue and many adipocytes (about $80 \%$ show a distinct perinuclear IGF-I staining). We assume that most of the IGF-I mRNA was expressed by adipocytes. The participation of IGF-I during ductal development by a paracrine mechanism is possible, since IGF-I expression was relatively high in virgin heifers. Locally produced IGFBP-1 may modulate IGF actions as suggested by the higher IGFBP-1 mRNA expression. The mechanism for an inhibitory or stimulatory activity of IGF-I by IGFBP appears to be a competition for binding to the IGFR (Cohick 1998). During pregnancy the immunohistochemical localisation of IGF-I did not change. The lower expression of mRNA for IGF-I by RPA (days 194-213 of pregnancy) suggests the action of other local modulating factors. This decrease was followed by an increase during advanced pregnancy (days 255272). Placental oestrogen could be an important competence factor for expression changes and correlates with increasing oestradiol-17 $\beta$ levels in blood plasma (Theyerl-Abele et al. 1990). A similar increase of IGF-I expression during pregnancy was described in the sow (Lee et al. 1993), although the regulation may be species specific, because oestradiol seems to downregulate the IGF-I and IGFR-1 expression in swine (Lee et al. 1993). In mice the IGF-I expression was reinitiated at the end of pregnancy (Richert \& Wood 1999) and this agrees with the cow data. IGF-I stimulates the proliferation of bovine mammary epithelial cells in vitro (McGrath et al. 1991) and in vivo (Collier et al. 1993). These observations may indicate a role for endocrine or paracrine IGF-I during late pregnancy lobuloalveolar development, modulated by increased oestradiol levels.
The IGFBP-3 mRNA expression decreased significantly during late lactation when compared with mammogenesis. Additionally, mammary IGFBP-3 protein secretion was higher during the late pre-partum period and involution than during lactation (Baumrucker \& Erondu 2000). Interestingly, lactoferrin specifically binds to IGFBP-3 and causes competitive displacement of IGF from IGF-IGFBP-3 complexes, thereby providing free IGF for the receptor (Baumrucker \& Erondu 2000). Dehoff et al. (1988) and Hadsell et al. (1990) described an increase of IGF-I binding during lactogenesis. The weak immunohistochemical staining for IGF-I protein and the lower mRNA expression of IGF-I during lactogenesis and galactopoiesis may indicate a minor function of local IGF-I during that period. Alternatively, high expression of IGFR-1 may suggest an increased importance for the endocrine IGF-I (produced by the liver) and may explain the well-known galactopoietic effect of exogenous GH (Schams et al. 1991). For goats, endocrine IGF-I inhibits apoptosis in mammary epithelial cells rather than affecting the secretory activity of epithelial cells (Knight \& Wilde 1993). Moreover, treatment of cows with somatotrophin did not increase the expression of IGF-I in the mammary gland (Sharma et al. 1994).

During involution, IGF-I expression increased again in the mammary gland. Immunohistochemical analyses revealed that during this phase, in contrast to previously examined stages, IGF-I was distinctly localised in the cubic epithelium of small and large acini, in the epithelium of ducts and weakly of the intralobular stroma. This localisation of the IGF-I protein correlates with the measured increase of mRNA expression, suggesting local production. The results lead us to conclude that IGF-I is probably an important local factor for remodelling of the bovine mammary gland during involution. This may be a direct effect of IGF-I or of synergistic actions with other growth factors. A synergistic interaction between IGF-I and transforming growth factor- $\alpha$ (TGF- $\alpha$ ) has been suggested by Forsyth et al. (1998), and significant expression of TGF- $\alpha$ mRNA in the bovine mammary gland (Plath et al. 1997) supports this notion.

Throughout mammogenesis and lactation the IGF-II expression in the mammary tissue was relatively high and constant when compared with lower expression during involution. IGF-II stimulates the proliferation of mammary epithelial cells in vitro (Collier et al. 1993), although with a lower potency than IGF-I (Peri et al. 1992). IGF-II mRNA was also detected in ovine mammary epithelial cells (Forsyth et al. 1995). It is interesting to note that in sheep foetal mammary tissue IGF-II was more highly expressed than IGF-I (Forsyth et al. 1999). IGF-II may be more important during embryonic development (Adams 1983). Nevertheless, in the adult we assume that there is a significant role of IGF-II during mammogenesis, because in a mouse mammary cell line IGF-II seemed to increase cellular growth and reduce differentiation (Lykos et al. 2000). 
The distinct upregulation of IGFBP-1 and -5 during specific periods suggests physiological functions for these periods. In contrast to our results with non-detected levels in the bovine mammary tissue, the IGFBP-5 mRNA concentration is increased during involution in rat mammary tissue. It has been proposed that IGFBP-5 inhibits IGF-I-mediated cell survival (Tonner et al. 1997). We do not have a clear explanation for the species differences observed. One explanation could be the timing of material collection. The bovine mammary gland tissue was collected relatively late (3-4 weeks after dry-off). Therefore further studies with a better timing of material collection (starting shortly after dry-off) are needed. The other possibility are species differences in IGFBP expression as indicated in the literature (Albiston et al. 1995, Flint et al. 2000). Because IGFBP-2 and -6 expression in the bovine mammary gland was very weak, we conclude that it is not regulated and does not have a significant physiological role in the bovine mammary gland. Nevertheless, the IGFBP-2 mRNA expression in the ovine mammary tissue seems to be regulated, because it was significantly lower in lactating than in pregnant sheep (Klempt et al. 1993).

The GHR mRNA was highly expressed in all stages examined. The receptor protein was also demonstrated in the same mammary gland samples by immunohistochemistry and in situ hybridisation in the epithelial and stromal compartments (Sinowatz et al. 2000). Therefore, a direct effect of $\mathrm{GH}$ on development and function of the bovine mammary gland seems to be indicated.

In conclusion, locally produced IGF-I and -II may play a role during mammary development in virgin and pregnant heifers. A high IGFR expression compared with a lower IGF-I and IGFBP-3 expression during galactopoiesis suggests a function for the endocrine IGF-I during this stage. The increase of IGF-I mRNA during involution and immunohistochemistry indicates that it may be functionally important during this stage of remodelling.

\section{Acknowledgements}

This work was supported by the German Research Foundation (Scha 257/13-1). We thank Dr A Skottner (Kabi Pharmacia, Stockholm) for the supply of IGF-I antiserum and Dr G J Killian for critical reading of this manuscript.

\section{References}

Adams SO, Nissley SP, Handwerger S \& Rechler MM 1983 Developmental patterns of insulin-like growth factor-I and -II synthesis and regulation in rat fibroblasts. Nature 302 150-153.

Albiston AL, Saffery R \& Herington AC 1995 Cloning and characterization of the promoter for the rat insulin-like growth factor binding protein-3 gene. Endocrinology 136 696-704.

Ballard J, Baxter R, Binoux M, Clemmons D, Drop S, Hall K, Hintz R, Rechler M, Rutanen E \& Schwander J 1989 On the nomenclature of the IGF binding proteins. Acta Endocrinologica 121 $751-752$.
Baumrucker CR \& Erondu NE 2000 Insulin-like growth factor (IGF) system in the bovine mammary gland and milk. Journal of Mammary Gland Biology and Neoplasia 5 53-64.

Baumrucker CR, Campana WM, Gibson CA \& Kerr DE 1993 Insulin-like growth factors (IGF) and IGF binding proteins in milk: sources and functions. Endocrine Regulations 27 157-172.

Breier BH \& Sauerwein H 1995 Regulation of growth in ruminants by the somatotropic axis. In Ruminant Physiology: Digestion, Metabolism, Growth and Reproduction, pp 102-123. Eds W Engelhardt, S Leonhard-Marek, G Breves \& D Giesecke. Stuttgart: Enke Verlag.

Campbell PG, Skaar TV, Vega JR \& Baumrucker CR 1991 Secretion of insulin-like growth factor-I (IGF-I) and IGF-binding proteins from bovine mammary tissue in vitro. Journal of Endocrinology 128 219-228.

Cohick WS 1998 Role of the insulin-like growth factors and their binding proteins in lactation. Journal of Dairy Science 81 1769-1777.

Collier RJ, McGrath MF, Byatt JC \& Zurfluh LL 1993 Regulation of bovine mammary growth by peptide hormones: involvement of receptors, growth factors and binding proteins. Livestock Production Science 35 21-33.

Dehoff MH, Elgin RG, Collier RJ \& Clemmons DR 1988 Both type I and II insulin-like growth factor receptor binding increase during lactogenesis in bovine mammary tissue. Endocrinology 122 2412-2417.

Flint DJ, Tonner E \& Allan GJ 2000 Insulin-like growth factor binding proteins: IGF-dependent and -independent effects in the mammary gland. Journal of Mammary Gland Biology and Neoplasia $\mathbf{5}$ $65-73$

Forsyth IA, Taylor JA, Villa M \& Gilmour RS 1995 Evidence of growth factor production by sheep myoepithelial cells: potential for autocrine/paracrine interactions. In Intercellular Signalling in the Mammary Gland, pp 83-85. Eds CJ Wilde, M Peaker \& CH Knight. New York: Plenum Publishing Company.

Forsyth IA, Taylor JA \& Moorby CD 1998 DNA synthesis by ovine mammary alveolar epithelial cells: effects of heparin, epidermal growth factor-related peptides and interaction with stage of pregnancy. Journal of Endocrinology 156 283-290.

Forsyth IA, Gabai G \& Morgan G 1999 Spatial and temporal expression of insulin-like growth factor-I, insulin-like growth factor-II and the insulin-like growth factor-I receptor in the sheep fetal mammary gland. Journal of Dairy Research 66 35-44.

Gabler C, Lauer B, Einspanier A, Schams D \& Einspanier R 1997 Detection of mRNA and immunoreactive proteins for acidic and basic fibroblast growth factor (aFGF/bFGF) and expression of the fibroblast growth factor receptor (FGFR) in the bovine oviduct. Journal of Reproduction and Fertility 109 213-221.

Glimm DR, Baracos VE \& Kennelly JJ 1990 Molecular evidence for the presence of growth hormone receptors in the bovine mammary gland. Journal of Endocrinology 126 R5-R8.

Glimm DR, Baracos VE \& Kennely JJ 1992 Northern and in situ hybridization analyses of the effects of somatotropin on bovine mammary gene expression. Journal of Dairy Science 75 2687-2705.

Gluckmann PD \& Breier BH 1987 Physiology of the somatotropic axis with particular reference to the ruminant. Journal of Dairy Science 70 442-466.

Hadsell DL, Campbell PG \& Baumrucker CR 1990 Characterization of the change in type I and II insulin-like growth factor receptors of bovine mammary tissue during pre- and postpartum periods. Endocrinology 126 637-643.

Hauser SD, McGrath MF, Collier RJ \& Krivi GG 1990 Cloning and in vivo expression of bovine growth hormone receptor mRNA. Molecular and Cellular Endocrinology 72 187-200.

Holly JMP \& Wass JAH 1989 Insulin-like growth factors; autocrine, paracrine or endocrine? New perspectives of the somatomedin hypothesis in the light of recent developments. Journal of Endocrinology 122 611-618. 
Hsu SM, Raine L \& Fanger H 1981 Use of avidin-biotin-peroxidase complex (ABC) in immunoperoxidase techniques: a comparison between $\mathrm{ABC}$ and unlabeled antibody (PAP) procedures. Journal of Histochemistry and Cytochemistry 29 577-580.

Jones JI \& Clemmons DR 1995 Insulin-like growth factors and their binding proteins: biological actions. Endocrine Reviews 16 3-34.

Karg H, Schams D \& Mayer H 1988 Endokrine Grundlagen der Laktation und Naehrstoffverteilung. BST Symp. Nov. 1987 Braunschweig. Landbauforschung Voelkenrode Sonderheft 88 79-103.

Klempt M, Breier BH, Min SH, MacKenzie DD, McCutcheon SN \& Gluckmann PD 1993 IGFBP-2 expression in liver and mammary tissue in lactating and pregnant ewes. Acta Endocrinologica 129 453-457.

Knight CH \& Wilde CJ 1993 Mammary cell changes during pregnancy and lactation. Livestock Production Science 35 3-19.

Lee CY, Bazer FW \& Simmen FA 1993 Expression of components of the insulin-like growth factor system in pig mammary glands and serum during pregnancy and pseudopregnancy: effects of oestrogen. Journal of Endocrinology 137 473-483.

Lykos MA, Fligger JM, Staley MD \& Baumrucker CR 2000 Autocrine insulin-like growth factor II inhibits beta-casein mRNA expression in a mammary cell line. Journal of Dairy Science $\mathbf{8 3}$ 285-295.

Massague J \& Czech MP 1982 The subunit structures of the two distinct receptors for insulin-like growth factors I and II and their relationship to the insulin receptor. Journal of Biological Chemistry 257 5038-5045.

McGrath MP, Collier RJ, Clemmons DR, Busby WH, Sweeny CA \& Krivi GG 1991 The direct in vitro effect of insulin-like growth factors (IGFs) on normal bovine mammary cell proliferation and production of IGF binding proteins. Endocrinology 129 671-678.

Peri I, Shamay A, McGrath MF, Collier RJ \& Gertler A 1992 Comparative mitogenic and galactopoietic effects of IGF-I, IGF-II and DES-3-IGF-I in bovine mammary gland in vitro. Cell Biology International Reports 16 359-368.

Plath A, Peters F \& Einspanier R 1996 Detection and quantitation of specific mRNAs by ribonuclease protection assay using denaturing horizontal polyacrylamide gel electrophoresis: a radioactive and nonradioactive approach. Electrophoresis 17 471-472.

Plath A, Einspanier R, Peters F, Sinowatz F \& Schams D 1997 Expression of transforming growth factors alpha and beta-1 messenger RNA in the bovine mammary gland during different stages of development and lactation. Journal of Endocrinology 155 501-511.

Rechler MM \& Nissley SP 1985 The nature and regulation of the receptors for insulin-like growth factors. Annual Review of Physiology 47 425-442.

Richert MM \& Wood TL 1999 The insulin-like growth factors (IGF) and IGF type I receptor during postnatal growth of the murine mammary gland: sites of messenger ribonucleic acid expression and potential functions. Endocrinology 140 454-461.

Schams D, Graf F, Meyer J, Graule B, Mauthner M \& Wollny C 1991 Changes of hormones, metabolites and milk after treatment with sometribove (recombinant methionyl bST) in Deutsches Fleck- and German Black and White cows. Journal of Animal Science 69 1583-1592.

Sharma BK, Vandehaar SJ \& Ames NK 1994 Expression of insulinlike growth factor-I in cows at different stages of lactation and in late lactation cows treated with somatotropin. Journal of Dairy Science $772232-2241$.

Sinowatz F, Schams D, Kolle S, Plath A, Lincoln D \& Waters MJ 2000 Cellular localisation of GH receptor in the bovine mammary gland during mammogenesis, lactation and involution. Journal of Endocrinology 166 503-510.

Theyerl-Abele M, Meyer HHD, Schams D \& Karg H 1990 Concentrations of IGF-I and estradiol-17 beta in the blood plasma of pregnant cattle. Deutsche Tierä rztliche Wochenschrift 97 382-385.

Tonner E, Barber MC, Travers MT, Logan A \& Flint DJ 1997 Hormonal control of insulin-like growth factor-binding protein-5 production in the involuting mammary gland of the rat. Endocrinology 138 5101-5107.

Winger QA, de los Rios P, Han VK, Armstrong DT, Hill DJ \& Watson AJ 1997 Bovine oviductal and embryonic insulin-like growth factor binding proteins: possible regulators of 'embryotrophic' insulin-like growth factor circuits. Biology of Reproduction 56 1415-1423.

Received 16 June 2000

Revised manuscript received 25 September 2000 Accepted 29 September 2000 